\title{
Plaintiff as Deponent: Invoking the Fifth Amendment
}

Whether a plaintiff who brings a civil action in a federal court may invoke the fifth amendment privilege against self-incrimination on deposition and still maintain his suit is an unsettled question. The Supreme Court has never decided the issue, and lower courts disagree as to its proper resolution.

Many courts have held that a plaintiff may invoke the fifth amendment at his deposition, but only at the cost of having his case dismissed. Several expressed rationales underlie these decisions. One viewpoint distinguishes the plaintiff's invocation of the fifth amendment from that of the defendant by emphasizing the "voluntariness" of the plaintiff"s role as litigant. ${ }^{1}$ The plaintiff, by bringing suit, is deemed to have "waived" his fifth amendment privilege. Another approach focuses on the obstructiveness of a plaintiff who refuses to answer any questions on deposition. ${ }^{2}$ State courts have also used the equitable doctrine of "clean hands" to dismiss a number of divorce cases, and their reasoning has been cited by a number of federal courts in different contexts. ${ }^{3}$

A variety of rationales similarly emerges in the decisions that uphold a plaintiff's right to maintain his suit after proper invocation of the fifth amendment on deposition. A number of courts have relied on the general notion that a constitutional privilege may not be made "costly." Other courts have noted that dismissal may be proper in the face of a willful default by the plaintiffs or when there are other circumstances justifying dismissal as a last resort. ${ }^{6}$ Finally, one circuit recently has approved an explicit balancing test that weighs the interests of the plaintiff in invoking the

1 See text and notes at notes 27-38 infra.

2 See text and notes at notes 39-45 infra.

3 See text and notes at notes 46-51 infra.

- See text and notes at notes 52-69 infra.

- Campbell v. Gerrans, 592 F.2d 1054 (9th Cir. 1979); see text and notes at notes 72-81 infra.

- Thomas v. United States, 531 F.2d 746 (5th Cir. 1976); see text and notes at notes 8286 infra. 
fifth amendment privilege against the defendant's need for discovery. ${ }^{7}$

It is the thesis of this comment that the plaintiff has an absolute right to invoke the fifth amendment on deposition without suffering dismissal of his suit. This result is mandated by the logical, practical, and constitutional infirmities of all other approaches to the problem; by the clear language and purpose of the discovery rules; by the constitutional limitations on the imposition of discovery sanctions under rule $37(\mathrm{~b})$; and by the now-definite availability of adverse inferences in civil trials.

\section{The Fifth Amendment and Depositions: The General Case}

The scope of discovery in federal civil litigation is indisputably broad. The range of information subject to discovery is defined by relevance: a witness may be examined "regarding any matter, not privileged, which is relevant to the subject matter involved in the pending action."8 So vast is the range of relevance that it has been couched in the negative: discovery will be allowed unless the information sought is clearly irrelevant." Although purely collateral points usually are not subject to discovery, courts will allow discovery on a wide range of issues, including any information that might bear on the witness's credibility. ${ }^{10}$ It is no ground for objection that the testimony may be inadmissible at trial. ${ }^{11}$

Despite the breadth of the areas subject to discovery, the Federal Rules specifically reserve privileged matters as islands of silence. Procedurally, the laws of evidence governing the actual trial also govern examination by deposition; an objection that would be proper at trial on the ground that the matter was privileged would also be proper in discovery. ${ }^{12}$ At the deposition a deponent may refuse to disclose privileged matter, because the officer before whom the deposition is taken cannot compel testimony or punish

7 Wehling v. Columbia Broadcasting Sys., 608 F.2d 1084 (5th Cir. 1979); see text and notes at notes $87-95$ infra.

Fed. R. Crv. P. 26(b)(1).

- Independent Prods. Corp. v. Loew's, Inc., 22 F.R.D. 266, 271 (S.D.N.Y. 1958).

${ }^{10}$ Id. See also 4 J. Moore, Federal Practice I 26.56[1], at 26-117 (2d ed. 1979).

1222 F.R.D. at 271. "If the objection goes merely to admissibility, he must answer the question and his objection will be preserved and ruled upon when and if the deposition is presented." 4A J. Moore, supra note 10, II 37.02[2], at 37-32 (footnote omitted).

$124 \mathrm{~J}$. MOORE, supra note 10, I 26.60[1], at 26-225 to -227 . "However, a party cannot claim privilege against the disclosure of certain information at the discovery stage, and then defeat a motion for summary judgment on the allegation that he may choose to produce the evidence at trial." Id. I 26.60[1], at 26-227 (footnote omitted). 
the deponent for contempt. The proponent of the question, however, may suspend the examination and apply to the court for an order compelling answers, or he may complete the examination and then move for such an order. ${ }^{13}$ Either in advance or at the time of the defendant's motion, a party may move for a protective order under rule $26(\mathrm{c})$ to foreclose inquiry into privileged matters. Given the broad scope of discovery, however, it is unlikely that the court will grant such an order in advance of the deposition unless it is clear that the information is privileged. ${ }^{14}$

It is settled that the fifth amendment privilege against selfincrimination applies in civil cases as well as in criminal proceedings. ${ }^{10}$ The nature of the privilege is such that it "must be accorded liberal construction in favor of the right it was intended to secure." Whether the privilege is invoked in a criminal or in a civil proceeding, the test of whether a question is subject to the privilege is the same. "[I]t need only be evident from the implications of the question, in the setting in which it is asked, that a responsive answer to the question or an explanation of why it cannot be answered might be dangerous because injurious disclosure could result."17 The privilege has been construed broadly; injurious disclosure includes not only answers that would themselves support a conviction under a criminal statute, but also those that "would furnish a link in the chain of evidence necessary to prosecute one under a criminal statute."18 The right to assert the privilege against self-incrimination depends only upon the existence of a possibility of prosecution, not upon its likelihood. ${ }^{19}$

1s Fed. R. Civ. P. 37(a)(2).

$144 \mathrm{~J}$. Moore, supra note 10 , $\{26.60$ [5], at 26-251; $4 \mathrm{~A}$ id. If 37.02 , at 37-32. In fact, most such cases do not involve clearly privileged information, and the courts are unanimous in requiring a deponent to attend a deposition and invoke the privilege to each question. See Guy v. Abdulla (In re Lowers), 58 F.R.D. 1, 2 (N.D. Ohio 1973); Gulf Oil Corp. v. The Tug Kate Malloy, 291 F. Supp. 816, 818 (E.D. La. 1968).

${ }^{15}$ McCarthy v. Arndstein, 266 U.S. 34, 40 (1924); Guy v. Abdulla (In re Lowers), 58 F.R.D. 1, 2 (N.D. Ohio 1973). "Generally, facts concerning questions of civil liability are outside the scope of the privilege against self-incrimination; but the privilege may be asserted in any civil proceeding or pre-trial examination where there is a reasonable apprehension of criminal prosecution." Duffy v. Currier, 291 F. Supp. 810, 814 (D. Minn. 1968).

${ }^{10}$ Hoffman v. United States, 341 U.S. 479, 486 (1951).

17 Id. at $486-87$.

18 Gulf Oil Corp. v. The Tug Kate Malloy, 291 F. Supp. 816, 818 (E.D. La. 1968); see Blau v. United States, 340 U.S. 159, 161 (1950).

19 In re Master Key Litigation, 507 F.2d 292, 293 (9th Cir. 1974). See also Hoffman v. United States, 341 U.S. 479, 486-89 (1951); Isaacs v. United States, 256 F.2d 654, 658 (8th Cir. 1958). "Possibility" of prosecution refers to legal possibility-for example, that no immunity has been granted, that the statute of limitations has not run, or that prosecution 
This broad standard for invocation of the fifth amendment applies to witnesses and parties on deposition as long as the privilege is invoked in a procedurally acceptable manner. Thus, the Seventh Circuit recently emphasized that a witness has the right to claim fifth amendment protection on deposition as long as the possibility of prosecution is not fanciful. ${ }^{20}$ It is clear from the case law, however, that courts will not tolerate a blanket refusal by a deponent to participate in all discovery pertaining to an action that could have criminal implications. Rather, a privilege must be claimed with specificity by a refusal to answer a particular question or questions. ${ }^{21} \mathrm{~A}$ deponent must attend the deposition and answer questions until there is a reasonable danger that continuing to answer will tend to incriminate him. ${ }^{22}$ The trial court has the discretion to evaluate the adequacy of a claim of privilege, using the "possibility of prosecution" as the proper standard. ${ }^{23}$

As long as he stays within the procedure elaborated above, the deponent may pick the point beyond which he will "refuse to answer any questions about a matter already discussed, even if the facts already revealed are incriminating, as long as the answers sought may tend to further incriminate him."24 That a deponent already has revealed incriminating information earlier at the deposition or prior to its commencement is discussed by the courts under the concept of waiver. The opposing party in these cases claims that the deponent has "waived" the fifth amendment by divulging incriminating material. In Duffy $v$. Currier, ${ }^{25}$ for example, the plaintiff argued that the defendant had waived his privilege by answering certain interrogatories. The court rejected this contention and concluded that answers to interrogatories did not constitute a general waiver of the fifth amendment. ${ }^{28}$

would not place the defendant in double jeopardy. See In re Folding Carton Antitrust Litigation, 609 F.2d 867, 872 (7th Cir. 1979).

${ }^{20}$ In re Folding Carton Antitrust Litigation, 609 F.2d 867, 871 (7th Cir. 1979).

21 See cases cited note 14 supra.

22 Guy v. Abdulla (In re Lowers), 58 F.R.D. 1, 2 (N.D. Ohio 1973).

23 In re Folding Carton Antitrust Litigation, 609 F.2d 867, 871 (7th Cir. 1979).

24 In re Master Key Litigation, 507 F.2d 292, 294 (9th Cir. 1974) (emphasis in original). The court made this statement regardless of "the rule with respect to such a 'waiver' by a criminal defendant who elects to take the stand in his own behalf." Id. See also Brown v. United States, 356 U.S. 148 (1958).

${ }^{25} 291$ F. Supp. 810 (D. Minn. 1968).

26 Id. at 814-15. The Court stated that no waiver existed "except to the extent and scope to which the answers therein contained may be used in any subsequent trial or other proceedings." Id. at 814. 
II. Rationales for Dismissing the Plaintiff's Suit

Plaintiffs often have been subjected to sanctions under the discovery rules, even if they have observed the proper procedures for invoking the fifth amendment on deposition. Courts that have approved the dismissal of the plaintiff's suit as the proper sanction in such cases have operated under several rationales.

\section{A. The Voluntary/Involuntary Distinction}

One theme in the opinions imposing dismissal is that the plaintiff, as the party voluntarily before the court, is deemed to have waived his right to invoke the fifth amendment. Although the plaintiff is allowed to invoke the fifth amendment, he must suffer dismissal for doing so.

The first federal case to address the question relied on this line of reasoning, although the plaintiff actually had not raised the fifth amendment in response to questions on deposition. In Independent Productions Corp. v. Loew's, Inc. ${ }^{27}$ a private antitrust action, the defendant attempted to depose the corporate plaintiff's president. The deponent claimed a testimonial privilege of silence under the first amendment. In response, the court stated that "[t]he purpose of the First Amendment is to prevent oppression and censorship by the Government of the rights of individuals. That Amendment protects the right to express one's views. It does not relate to the privilege of silence," ${ }^{28}$ and concluded that "there is no testimonial privilege of silence based on the First Amendment."29

The Loew's court proceeded to assume that even if there were such a privilege, it would have been waived under the circumstances of the case, because "[i]t would be uneven justice to permit plaintiffs to invoke the powers of this court for the purpose of seeking redress and, at the same time, to permit plaintiffs to fend off questions, the answers to which may constitute a valid defense or materially aid the defense."30 Furthermore, although the plaintiffs in Loew's did not invoke the fifth amendment at deposition, the court, employing the same reasoning it used in the discussion of first amendment waiver, deemed the plaintiffs to have waived

\footnotetext{
2722 F.R.D. 266 (S.D.N.Y. 1958),

28 Id. at 275.

29 Id. at 276.

so Id.
} 
whatever fifth amendment privilege might have existed. ${ }^{31}$ The court swept aside the privilege expressly granted in rule 26 , and coined the best-known metaphor in the literature on the subject: "[The plaintiff] cannot use this asserted privilege as both a sword and a shield. Defendants ought not to be denied a possible defense because plaintiffs seek to invoke an alleged privilege." 32

The voluntary/involuntary distinction can be attacked most easily by challenging the underlying assumption that a plaintiff is voluntarily before the court..$^{33}$ Although a plaintiff technically is the party bringing the suit, there are many situations in which it is hardly accurate to say that the plaintiff is "in court voluntarily." Suppose, for example, a victim of a beating brings an action for assault and battery. It is impossible to conclude that such a plaintiff "has made the election to create an imbalance in the pans of the scales [of justice]," tic- to assert that the defendant has created the imbalance, which the plaintiff seeks to rectify through the legal process.

Under the theory that a plaintiff is by definition voluntarily before the court, such a victim would have his suit dismissed in cases where he invoked his constitutional right to avoid selfincrimination at deposition. Such a policy would consistently deny the civil rights of anyone vulnerable to criminal prosecution. For example, no one would be able to bring a suit for police brutality if on deposition he were required to elect between incriminating him-

s1 Id. at 278-79. The fifth amendment was at issue in Loew's because the court ruled that the plaintiff could be questioned with regard to why he had invoked the privilege before the House Committee on Un-American Activities. Id. at 272-73.

32 Id. at 277.

ss The voluntary/involuntary distinction can be challenged on two other grounds. The first is procedural. Even if one assumes that a plaintiff is bringing suit voluntarily, it cannot be said that the plaintiff is being deposed voluntarily; he must submit to discovery and its broad range of inquiry. A second objection recognizes that whether the party in question is the plaintiff or defendant in the civil suit is irrelevant for fifth amendment purposes, because the procedural posture of either party will be the same in the potential criminal suit-that of a defendant.

s4 Lyons v. Johnson, 415 F.2d 540, 542 (9th Cir. 1969), cert. denied, 397 U.S. 1027 (1970). A simple hypothetical illustrates the injustice that would result in this situation under the jurisdictions that favor dismissal of a plaintiff's suit:

$X$ is robbed at gunpoint. Before fleeing, the assailant beats her severely. $X$ brings suit for assault and battery. During the course of pretrial proceedings the defendant deposes $X$ and asks her questions relating to her activities as a prostitute. $X$ objects to the questions as being irrelevant and beyond the scope of discovery, but the court overrules her objection on the ground that the line of questioning may reflect on her credibility. Not wanting to subject herself to criminal liability, $X$ invokes her fifth amendment privilege against selfincrimination. 
self with regard to the incident out of which the claims arose, and suffering dismissal. . $^{\text {s }}$

One court has correctly described this situation. In Wehling $v$. Columbia Broadcasting System, ${ }^{36}$ the Fifth Circuit noted that "[a]lthough the plaintiff-defendant distinction has its advocates, . . . we are unwilling to join their ranks. It is true that, as a voluntary litigant, the civil plaintiff has created the situation which requires him to choose between his silence and his lawsuit,"37 but the court concluded that, in most cases, "a party 'voluntarily' becomes a plaintiff only because there is no other means of protecting legal rights." 38

\section{B. The Obstructive Plaintiff}

A blanket refusal to answer questions at deposition on the ground that they are privileged is an improper invocation of the fifth amendment, irrespective of whether such a claim is made by a plaintiff, a defendant, or a witness. A dismissal based on such an invocation by the plaintiff in the leading case of Lyons $v$. Johnson $^{39}$ has been relied on by courts in subsequent cases as demonstrating the necessity of dismissal on the ground of obstructiveness, even in cases in which the fifth amendment has been correctly invoked in response to a particular question. ${ }^{40}$

In Lyons, the plaintiff was appealing dismissals of her civil rights damage actions and the denial of an injunction against, among others, a California deputy district attorney, several police officers, a magistrate of a municipal court, and an attorney who had been appointed to assist Lyons in defending misdemeanor charges. Proceedings on these charges had been suspended for a time because of doubts as to her sanity. Lyons's complaints alleged

ss Such was the situation facing the court in Campbell v. Gerrans, 592 F.2d 1054 (9th Cir. 1979), where the dismissal was reversed. See text at notes 72-81 infra. The court, however, never explicitly attacked the voluntary/involuntary distinction. Other courts that upheld plaintiffs' suits, see Justice v. Laudermilch, 78 F.R.D. 201 (M.D. Pa. 1978); Alioto v. Holtzman, 320 F. Supp. 256 (E.D. Wis. 1970), did not attack this distinction either.

se 608 F.2d 1084 (5th Cir. 1979). For further discussion of Wehling, see text at notes 8795 infra.

s7 Id. at 1089 n.10.

ss Id.

39415 F.2d 540 (9th Cir. 1969), cert. denied, 397 U.S. 1027 (1970).

10 See Penn Communications Specialties, Inc. v. Hess, 65 F.R.D. 510 (E.D. Pa. 1975); Bramble v. Kleindienst, 357 F. Supp. 1028, 1036 (D. Colo. 1973), aff'd sub nom. Bramble v. Richardson, 498 F.2d 968 (10th Cir.), cert. denied, 419 U.S. 1069 (1974); Brown v. Ames, 346 F. Supp. 1176 (D. Minn. 1972). 
a conspiracy and other acts against her, all of which she claimed were directed at confining her to a state mental institution.

After having ignored a number of notices to appear for a deposition, the appellant finally appeared under court order; after stating her name, however, Lyons invoked the fifth amendment in response to all other inquiries. These inquiries pertained to her version of the incidents and other information on which she was basing her claims. The lower court had dismissed her suits because of her "continued and unyielding refusal to submit herself to any depositional interrogation or discovery whatsoever in relation to her claims."1 As the appellate court noted in affirming the dismissals, "[i]t is a little difficult to visualize how a possibility of selfincrimination could be involved in any mere relevant interrogation of appellant as to the background, aspects and incidents of her asserted claims . . . ."42 The Lyons court could have upheld the dismissal on the ground that the privilege had been invoked incorrectly, but it believed that it was addressing the situation of a plaintiff properly invoking the fifth amendment on deposition, as it repeated the Loew's sword-and-shield metaphor ${ }^{43}$ and then stated that "[t]he scales of justice would hardly remain equal in these respects, if a party can assert a claim against another and then be able to block all discovery attempts against him by asserting a Fifth Amendment privilege to any interrogation whatsoever upon his claim." This arguably ambiguous passage is often employed out of context as support in cases that dismiss a plaintiff's suit, ${ }^{45}$ even when the privilege is invoked with correct specificity and not obstructively as it was in Lyons.

\section{Clean Hands}

The classic formulation of the equitable doctrine of "clean hands" as a prerequisite to the granting of relief by a court is that whenever a plaintiff, as the party setting the judicial machinery in motion, "has violated conscience, or good faith, or other equitable principle, in his prior conduct, then the doors of the court will be shut against him . . . ; the court will refuse . . . to award him any

11415 F.2d at 541 .

4 Id. at 542.

4s See text and note at note 32 supra.

4415 F.2d at 542 (emphasis added).

is See, e.g., Jones v. B.C. Christopher \& Co., 466 F. Supp. 213 (D. Kan. 1979); Penn Communications Specialties, Inc. v. Hess, 65 F.R.D. 510 (E.D. Pa. 1975). 
remedy." ${ }^{\prime \prime 8}$ A leading case applying the doctrine is Franklin $v$. Franklin, ${ }^{47}$ a 1955 Missouri divorce case. The court in Franklin found that the plaintiff could refuse to answer self-incriminating questions, but that when she did so her action would be judged by the same rule as if she had refused to answer any other pertinent questions: namely, that when proper discovery questions regarding relevant and material facts peculiarly and exclusively within the knowledge of the party are propounded, the party's refusal to answer justifies striking his pleadings.

Divorce is a statutory action, but the courts generally follow the rules of equity and apply equitable principles in determining the rights and liabilities of the parties. . . One seeking a divorce must prove himself to be the innocent and injured party. ... The latter requirement is neither more nor less than application of the equitable doctrine of "clean hands" to a divorce action. ${ }^{48}$

While it is not surprising that Franklin has been relied upon in a series of divorce cases, ${ }^{40}$ the reasoning also has been used in other contexts, ${ }^{\text {s0 }}$ apparently without a realization of the equitable origin of the clean hands doctrine. Cases like Franklin, however, should be distinguished from those not arising in equity; in the latter, the only relevant concern is the possible conflict between an interest in broad discovery and the protection of the plaintiff from self-incrimination. Employment of the doctrine out of its proper context amounts essentially to using it as a paraphrase for the voluntary/involuntary distinction, the shortcomings of which have been noted above. ${ }^{51}$

\section{Rationales for Not Dismissing the Plaintiff's Suit}

A. Spevack and Garrity: The Notion of Costliness

Several of the cases that uphold the plaintiff's right to invoke

48 J. Pomeroy, A Treatise on Equity Jurisprudence 91-92 (5th ed. S. Symons 1941).

47365 Mo. 442, 283 S.W.2d 483 (1955).

4 Id. at 446,283 S.W.2d at $485-86$.

4 Stockham v. Stockham, 168 So. 2d 320 (Fla. 1964); Minor v. Minor, 232 So. 2d 746 (Fla. App.), aff'd, 240 So. 2d 301 (Fla. 1970); Lund v. Lund, 161 So. 2d 873 (Fla. App. 1964); Christenson v. Christenson, 281 Minn. 507, 162 N.W.2d 194 (1968); Annest v. Annest, 49 Wash. 2d 62, 298 P.2d 483 (1956).

${ }^{\text {so }}$ See Lyons v. Johnson, 415 F.2d 540 (9th Cir. 1969), cert. denied, 397 U.S. 1027 (1970); Penn Communications Specialties, Inc. v. Hess, 65 F.R.D. 510 (E.D. Pa. 1975).

s1 See text and notes at notes 33-38 supra. 
the fifth amendment on deposition without suffering dismissal ${ }^{52}$ rely on a line of Supreme Court decisions that culminated in Spevack v. Klein ${ }^{53}$ and Garrity v. New Jersey. ${ }^{54}$ These companion cases, although not directly concerned with a plaintiff invoking the fifth amendment on deposition, both emphasize that imposing costly consequences on the assertion of a constitutional privilege effectively destroys the privilege.

In Spevack the Supreme Court reversed a decision of the New York Court of Appeals ${ }^{55}$ that had disbarred an attorney for professional misconduct consisting of the failure to produce financial records and to testify at a judicial inquiry. The attorney had defended on the ground that such production and testimony would incriminate him. The Court held that "the Self-Incrimination Clause of the Fifth Amendment . . . should not be watered down by imposing the dishonor of disbarment and the deprivation of a livelihood as a price for asserting it." "'s6 The Court stated that " "the Fifth Amendment guarantees . . . the right of a person to remain silent unless he chooses to speak in the unfettered exercise of his own will, and ... [that he shall] suffer no penalty ... for such silence." "sz "Penalty" was defined as "the imposition of any sanction which makes assertion of the Fifth Amendment privilege "costly." "\$8 Similarly, in Garrity the Court held that the compulsion inherent in the threat of forfeiture of a policeman's job unless he testified in a departmental disciplinary proceeding rendered that compelled testimony inadmissible in a subsequent criminal proceeding. ${ }^{58}$

The "costliness" reasoning of Spevack and Garrity was first used to allow a plaintiff to invoke the fifth amendment without suffering dismissal in a 1969 Florida divorce case, Simkins v. Simkins. ${ }^{60}$ In that case, an interlocutory appeal was taken from an order to answer addressed to the plaintiff husband who had refused to answer certain questions at his deposition. The Florida District

s2 Justice v. Laudermilch, 78 F.R.D. 201 (M.D. Pa. 1978); Simkins v. Simkins, 219 So. 2d 724 (Fla. App.), cert. dismissed, 225 So. 2d 916 (Fla. 1969).

s3 385 U.S. 511 (1967).

385 U.S. 493 (1967).

ss Klein v. Spevack, 16 N.Y.2d 1048, 213 N.E.2d 457, 266 N.Y.S.2d 126 (1965).

385 U.S. at 514. The Supreme Court thus overruled Cohen v. Hurley, 366 U.S. 117 (1961), which had affirmed a disbarment on a similar ground.

${ }^{37} 385$ U.S. at 514 (quoting Malloy v. Hogan, 378 U.S. 1, 8 (1964)).

38385 U.S. at 515.

so 385 U.S. at 496-98.

219 So. 2d 724 (Fla. App. 1969). 
Court of Appeals refused to follow Stockham v. Stockham, ${ }^{61}$ which had held that a plaintiff, as a party voluntarily before the court, could not invoke the fifth amendment and still maintain the suit; ${ }^{* 2}$ rather, the Simkins court relied on Spevack and Garrity and ruled that a privilege could not be made so costly.

The dissent in Simkins, however, concluded that Spevack and Garrity did not require a decision contrary to Stockham because in neither Supreme Court case was the party who sought protection against self-incrimination voluntarily seeking relief; both men had been summoned to appear. The dissenting judge stated that the Spevack and Garrity holdings applied "only to persons whom the law requires to appear before the bar of justice." quent case the majority of the court adopted this reasoning, and Simkins was overruled. ${ }^{64}$

In 1978, however, a federal court used Spevack as support for its denial of the defendant's motion to compel the plaintiff to answer certain deposition questions that the plaintiff claimed were incriminating. Justice $v$. Laudermilch ${ }^{65}$ was a civil rights action in which the plaintiff claimed that a state trooper had deprived him of his federal constitutional rights during a robbery. The questions that the plaintiff refused to answer at deposition pertained to his

62168 So. 2d 320 (Fla. 1964).

"2 For discussion of the "voluntariness" rationale for dismissal, see text and notes at notes 27-38 supra.

6s 219 So. 2d at 727 (Pearson, J., dissenting).

64 Minor v. Minor, 232 So. 2d 746 (Fla. App.), aff'd, 240 'So. 2d 301 (Fla. 1970). The plaintiff in this divorce action had invoked the fifth amendment on deposition in response to questions relating to the defendant's charge of adultery. The plaintiff brought an interlocutory appeal from the trial court's order compelling her to answer the questions or suffer dismissal of her complaint. The appellate court concurred with the Simkins dissent, and upheld Stockham and the trial judge:

Appellant's choice in this case is not, involuntarily, one between two totally disadvantageous alternatives, as were the choices in Garrity and Spevack . . . , but rather, voluntarily, one between two alternatives one of which can be employed to some advantage. Appellant can gain the affirmative relief she seeks from her choice, and the choice is freely hers; Garrity and Spevack on the other hand couldn't gain in any event, yet they were compelled to choose.

We conclude then, that appellant suffers no "penalty" in the sense spoken of in Spevack ....

Id. at 747 (emphasis in original).

The Garrity-Spevack rationale was similarly disapproved as a basis for allowing the plaintiff to invoke the fifth amendment without suffering dismissal in a federal case, Penn Communications Specialties, Inc. v. Hess, 65 F.R.D. 510 (E.D. Pa. 1975).

68 F.R.D. 201 (M.D. Pa. 1978). But see Jones v. B.C. Christopher \& Co., 466 F. Supp. 213 (D. Kan. 1979) (sharply criticizing the result in Justice as inconsistent with the weight of authority in the federal courts). 
use of drugs. Citing Spevack, the court stated that a privilege could not be made costly, and concluded that because the matters into which the defendant sought to probe were privileged, it would not dismiss the plaintiff's action for his failure to answer. ${ }^{86}$ The court made its reference to Spevack as support after dismissing the ruling in Loew's and Lyons with the simple statement that "this does not appear to us to be the law."

The prohibition against a constitutional privilege being made too "costly" has been instrumental in the cases that uphold a plaintiff's right to assert the fifth amendment at deposition and still maintain his suit. The costliness rationale, however, does not provide absolute protection to a plaintiff invoking the fifth amendment: how costly a sanction must be to trigger the Spevack ruling remains unanswered, and given the nature of the inquiry, it can only be answered in vague terms.

Furthermore, the courts that objected to the use of Spevack did so on the ground that in that case the petitioner had been called before the court involuntarily. ${ }^{68}$ Although the Spevack court did not exclude plaintiffs from its rule, the petitioner there was indeed before the court involuntarily. Thus, as long as a court is willing to abide by the dubious voluntary/involuntary distinction, ${ }^{69}$ the applicability of the Spevack costliness doctrine in cases involving plaintiffs is unclear.

\section{B. Recent Decisions}

Three recent decisions offer an analysis that derives in part from the costliness rationale while proceeding beyond it in some respects. These cases recognize the danger inherent in a rule calling for automatic dismissal of a plaintiff's suit, and they stress the exemption from discovery explicitly granted by rule 26 for privileged matter. ${ }^{70}$ None of the three decisions, however, found the privilege to be absolute, despite its statutory recognition. ${ }^{71}$

es 78 F.R.D. at 203.

67 Id. The court also disapproved, id., of Penn Communications Specialties, Inc. v. Hess, 65 F.R.D. 510 (E.D. Pa. 1975). The Penn court had dismissed the plaintiff's suit on the ground that the refusal to answer questions on deposition was obstructive. See text and notes at notes $39-45$ supra.

os Penn Communications Specialties, Inc. v. Hess, 65 F.R.D. 510, 512 (E.D. Pa. 1975); Minor v. Minor, 232 So. 2d 746, 747 (Fla. App.), aff'd, 240 So. 2d 301 (Fla. 1970).

- See text and notes at notes 27-38 supra.

20 Fed. R. Crv. P. 26(b)(1).

${ }^{21}$ In two of these opinions, Campbell v. Gerrans, 592 F.2d 1054 (9th Cir. 1979), and 
1. Dismissal for "Willful Default" and as a "Last Resort." The Ninth Circuit held in Campbell v. Gerrans ${ }^{72}$ that the trial court had abused its discretion in dismissing the plaintiffs' suit because of their invocation of the fifth amendment in response to interrogatories. The plaintiffs had brought a civil rights action for damages, ${ }^{73}$ alleging that they had been assaulted, and their personal property wrongly seized, by police officers during a drug raid. The defendant propounded thirty-four interrogatories; the plaintiffs claimed the fifth amendment with regard to four. The trial court, citing Lyons, dismissed the plaintiffs' suit; ${ }^{74}$ the Ninth Circuit remanded it for reinstatement.

The reasoning of the Ninth Circuit was straightforward: the Supreme Court has consistently held that the fifth amendment applies to all proceedings, "civil or criminal, administrative or judicial, investigatory or adjudicatory." "75 Referring to cases such as Franklin and Lyons, the court found that they were either distinguishable on their facts or based on the erroneous view that "all pleading of the Fifth Amendment in the discovery stage [is] improper." The court went on to say that "[c]learly there are cases where the refusal to answer is one which the discovery rules permit under the privileged matter exception. . . . Just as clearly, there are cases like Lyons where the refusal to answer is improper and subject to Rule 37 sanctions." 77 Thus, ten years after its decision in Lyons, the Ninth Circuit limited the holding of that case to discovery situations in which the invocation of the fifth amendment was itself objectionable.

The Campbell court, citing Spevack and Griffin v. California, ${ }^{78}$ stressed that "[i]mposing the harshest of the Rule 37 sanctions on a proper exercise of Fifth Amendment rights is not in accord with Supreme Court decisions," because dismissal would make assertion of the privilege costly. ${ }^{79}$ Referring to the case law involving the propriety of rule 37 sanctions, the court emphasized

Thomas v. United States, 531 F.2d 746 (5th Cir. 1976), the plaintiffs claimed the fifth amendment privilege in response to interrogatories propounded by the defendants, but the reasoning and holdings are equally applicable to deposition questions.

72592 F.2d 1054 (9th Cir. 1979).

73 The action was brought under 42 U.S.C. § 1983 (1976).

74 See 592 F.2d at 1056. The trial court's decision is not reported.

75 Id. at 1057 (quoting Kastigar v. United States, 406 U.S. 441, 444 (1972)).

78 592 F.2d at 1057.

72 Id.

78380 U.S. 609 (1965).

79592 F.2d at 1057-58. 
that the power to dismiss is limited: " 'general principles cannot justify denial of a party's fair day in court except upon a serious showing of willful default." "80 The court concluded that "[i]n light of the Supreme Court decisions on the Fifth Amendment privilege, a plea based on this privilege in the discovery stage of a civil case cannot automatically be characterized as 'willful default' resulting in dismissal."

In Thomas $v$. United States, ${ }^{82}$ the earlier of two Fifth Circuit decisions, the court reversed and remanded the lower court's dismissal of a taxpayer's refund action, ${ }^{\text {s3 }}$ stating that "[d]ismissal of the disobedient party's action with prejudice is a sanction of last resort, applicable only in extreme circumstances . . . . Consideration must be given to such factors as good faith, willful disobedience, gross indifference to the rights of the adverse party, deliberate callousness or gross negligence." 84 The court stressed that even if a discovery sanction were to be imposed, the taxpayer should nevertheless be given a chance to try to meet his burden of proof with regard to the assessment's validity: " 'there are constitutional limitations upon the power of courts, even in aid of their own valid processes, to dismiss an action without affording a party the opportunity for a hearing on the merits of his cause." "s8 The court added that if the lower court's dismissal were not reversed, the Government would routinely be able to abuse its power to assess by "filing interrogatories framed to oblige the taxpayer to incriminate himself or forego his lawsuit . . . . [D]ismissal of every suit for wagering tax refund by every taxpayer who invokes his Fifth Amendment right may be akin to forfeiture."

2. Balancing. The language in Thomas seemed to suggest

or Id. at 1058 (quoting Gill v. Stolow, 240 F.2d 669, 670 (2d Cir. 1957)).

592 F.2d at 1058.

531 F.2d 746 (5th Cir. 1976).

ss The taxpayer had been arrested and charged with engaging in an unlawful gambling operation. The Internal Revenue Service, having been furnished with seized records, made a jeopardy assessment against the taxpayer and collected part of it. The taxpayer filed a claim for a refund on the ground that the taxes had been illegally or erroneously assessed; the Government denied this claim in its answer. The Government then served 21 interrogatories, asking the taxpayer about his wagering activities and sources of income. The taxpayer answered 11 of the questions but invoked the fifth amendment as to the remaining 10 . The lower court dismissed the taxpayer's action with prejudice, holding that he had to choose between his lawsuit and his silence. Thomas v. United States, 384 F. Supp. 224 (N.D. Tex. 1974).

531 F.2d at 749.

ss Id. (quoting Societé Internationale v. Rogers, 357 U.S. 197, 209 (1958)).

so 531 F.2d at 749 . 
that the Fifth Circuit was heading toward an absolutist position, one that would forbid the dismissal of a plaintiff's suit where the fifth amendment privilege had been properly invoked. More recently, however, in Wehling $v$. Columbia Broadcasting System, ${ }^{87}$ the court decided that a balancing test was the best means for accommodating the rights of plaintiffs and the interests of defendants. In an opinion that relied on a variety of theories, the appellate court reversed the district court's dismissal under rule 37 of the plaintiff's libel action. ${ }^{88}$ Wehling had invoked the fifth amendment at deposition in response to questions related to his alleged abuse of federal loan programs. This conduct, the subject of a pending grand jury investigation, pertained directly to the accuracy of an allegedly libelous broadcast by the defendant. The information, therefore, was essential to a defense of the libel action.

On appeal, the plaintiff claimed that dismissal of his suit made the assertion of his constitutional privilege impermissibly costly. The court, however, agreed with CBS's contention that it would be unfair to permit the plaintiff to continue his lawsuit and deprive CBS of essential information. As support, the court cited the sword-and-shield metaphor of Lyons, but it distinguished that case by noting that Wehling had only asked that discovery be stayed until all threat of criminal liability had passed; he had not claimed the right to proceed to trial without answering the deposition questions posed by CBS.89

The Fifth Circuit held that, given the explicit privilege exception of rule 26 , the district court lacked authority to order the plaintiff to disclose privileged information and had erred in concluding that the plaintiff's assertion of the privilege automatically required dismissal. ${ }^{90}$ The court also found that dismissal would be unconstitutional because due process required a judicial determination of Wehling's civil action; to force him to choose between his fifth amendment right to silence and his lawsuit would be impermissibly costly and would require him to forego one constitutional right in order to assert another. ${ }^{91}$ Nevertheless, the court empha-

${ }^{87} 608$ F.2d 1084 (5th Cir. 1979).

Bs The plaintiff, the owner of a number of trade schools, claimed that a CBS news broadcast had defamed him by reporting that he had abused loan programs. Prior to the broadcast, the plaintiff had been subpoenaed by a federal grand jury, before which he had invoked the fifth amendment.

og Id. at 1087.

so Id.

91 Id. at 1088; see Simmons v. United States, 390 U.S. 377, 394 (1968) ("we find it 
sized that "a civil plaintiff has no absolute right to both his silence and his lawsuit. Neither, however, does the civil defendant have an absolute right to have the action dismissed any time a plaintiff invokes his constitutional privilege."

The court attempted to resolve the dilemma implicit in this situation by adopting a balancing test: "Instead of arbitrarily adopting a rule favoring CBS, the [district] court should have measured the relative weights of the parties' competing interests with a view toward accommodating those interests, if possible."93 Under this test, dismissal would be appropriate "only where other, less burdensome, remedies would be an ineffective means of preventing unfairness to defendant."

The Fifth Circuit stated that in the circumstances of this case, the balance tipped toward the plaintiff and that his motion for a protective order should have been granted. All discovery would therefore be stayed for three years, until the statute of limitations on the potential criminal prosecution had run. Notwithstanding the admitted undesirability of the three-year hiatus in the lawsuit from the viewpoint of both the court and the defendant, the court found this solution appropriate. The court noted, however, that dismissal, a "drastic remedy," might be appropriate if at some point it appeared that the time lapse would deprive CBS of crucial information. ${ }^{95}$

Thomas, Campbell, and Wehling all demonstrate a departure from the prior case law. While earlier cases, even those that allowed the plaintiff's suit, had offered little if any resistance to the notion that the fifth amendment privilege could be eclipsed by discovery, the Fifth and Ninth Circuits realized that the privilege exception was firmly grounded in rule 26. Despite this shared perception, however, the courts reversed the dismissals on other-if conceptually related-grounds. In so doing, each retreated from the clear language of the rule.

Neither the Ninth nor the Fifth Circuit has fully resolved the

intolerable that one constitutional right should have to be surrendered in order to assert another"). But see McGautha v. California, 402 U.S. 183, 212 (1971) ("the validity of [Simmons's] reasoning must now be regarded as open to question").

22608 F.2d at 1088.

s Id.

- Id. The court stated that although "dismissal is unavailable as a sanction, the district court is not precluded from using dismissal as a remedy to prevent unfairness to the defendant." Id. at 1087 n.6 (emphasis in original).

s Id. at 1089 . 
problem. In particular, neither has proposed an adequate solution to the most difficult situation: when the information sought is critical to the defendant's case. The Ninth Circuit in Campbell correctly emphasized that an attempt to block all discovery, as in Lyons, does not fall within the rule 26 exemption; rather, it is an improper invocation of the privilege. Nonetheless, the court left open the question of whether in some situations far less extreme than that of Lyons the plaintiff's invocation of the fifth amendment might be characterized as "willful default" and consequently lead to dismissal under rule 37 . The opinion offers little guidance concerning when such a characterization might prevail. ${ }^{96}$

Similarly, although the Wehling opinion indicates a relatively strong concern for the privilege exception, the Fifth Circuit's balancing test proceeds from the premise that "a civil plaintiff has no absolute right to both his silence and his lawsuit." Ad Aditionally, the Wehling decision can be criticized as contrived and impractical. To wait until the statute of limitations runs merely sidesteps the question of whether a plaintiff may invoke the fifth amendment on deposition and still maintain the suit; such a delay obviates the necessity of that invocation. More importantly, from the defendant's viewpoint it may be a far greater burden to wait out a lengthy statutory period than it would be to proceed in defending the suit without the information sought. The Wehling court itself recognized that postponing discovery for three years might preclude essential avenues of inquiry for CBS. Should that turn out to be the case, "the [district] court would be free to fashion whatever remedy is required to prevent unfairness to defendant." ${ }^{\text {"ss }}$ Wehling is of little precedential value, because if its particular resolution is unworkable in a given case, a lower court must balance the interests of the plaintiff and defendant to determine the appropriate remedy. The Wehling opinion does not delineate how this balance is to be achieved.

\section{Absolute Protection}

Rule 26(b)(1) provides for discovery "regarding any matter, not privileged, which is relevant to the subject matter involved in

os The information that the defendant sought to elicit from the plaintiff in Campbell was of marginal relevance to his case. The court, however, did not specifically limit its holding to questions of minimal relevance.

27608 F.2d at 1088.

${ }^{8}$ Id. at 1089. 
the pending action." 99 The words are absolute; they explicitly create a disjunction between discoverable matter and privileged matter. The trend in this area of the law has been toward recognition of this disjunction. ${ }^{100}$ The early cases that dismissed suits only paid lip service to the privilege exception: plaintiffs could invoke the privilege, but they had to suffer dismissal as a consequence. In the aftermath of Spevack, courts began to recognize that dismissal made the invocation impermissibly "costly."101 The Fifth and Ninth Circuits, although influenced by Spevack, accord a greater degree of respect to the privilege itself, while stopping short of absolute protection.

The underlying rationale for this equivocal approach seems to be similar to that employed by the earlier decisions approving the automatic dismissal of the plaintiff's suit: concern for the defendant's ability to defend the charges. While the early cases pointed confidently to the unfairness of permitting a plaintiff to bring suit and then to thwart the defendant's attempt to defend it, the new reasoning attempted to take account of the competing interests of both parties to the ligitation. The defendant may need the requested information in the preparation of his case, while the plaintiff has a fifth amendment right to silence and a due process right to a judicial determination of his civil action.

In cases in which the defendant is seeking essential information, however, the plaintiff's fifth amendment right will be respected only if the privilege exception to rule 26 is regarded as absolute. As analysis of the Wehling decision indicates, ${ }^{102}$ the balancing approved by that court is likely to result too often in a total

"Fed. R. Crv. P. 26(b)(1).

${ }^{100}$ See text and notes at notes 70-98 supra.

${ }^{101}$ In refusing to dismiss a case, one court squarely disputed the waiver theory, and upheld the privilege exception of rule 26 without relying on the notion of "costliness." In Aliotto v. Holtzman, 320 F. Supp. 256 (E.D. Wis. 1970), the court concluded that

the defendants err in their belief that the plaintiff's claim in this civil action grants them carte blanche to interrogate her about the criminal charge against her that was subsequently dismissed.

I believe that the plaintiff sufficiently responded to all fair discovery questions which were submitted to her, and that it would constitute improper harassment of the plaintiff to require her to undergo the additional, unjust discovery . . . in this motion. ... I am unable to spell out a waiver of the plaintiff's fifth amendment rights by reason of her complaint that the defendants illegally engaged in an electronic surveillance.

Id. at 257. The judge denied defendant's motion "notwithstanding the broad scope of discovery permitted under Rule 26(b)." Id.

102 See text and notes at notes 87-95 supra. 
abrogation of the plaintiff's rights. It can be asserted as a general proposition that a plaintiff's constitutional rights should not be balanced against a defendant's statutorily based entitlement to discovery. Specific support for a standard of absolute protection, however, derives from the language and purpose of the discovery rules themselves, from the constitutional limitations imposed by the Supreme Court on rule 37 , and from the relatively recent judicial approval of adverse inferences in the context of civil suits.

\section{A. The Purpose and Scope of Discovery}

There is nothing in the history of the Federal Rules to suggest that the disjunction between privileged and discoverable material created by rule $26(\mathrm{~b})(1)$ was not intended to be absolute. The Rules Enabling Act $^{\mathbf{1 0 3}}$ gave the Supreme Court the authority to make rules that would simplify pleading and practice in the federal courts, not to alter substantive rights. In accordance with this general goal, the rules dealing with discovery ${ }^{104}$ are designed to serve the modern procedural system, which aims to narrow the region of controversy and "to focus litigation upon matters which are likely to be dispositive of a case." 108 Discovery isolates those issues that are not really the subject of dispute, by revealing arguments with dispositive weaknesses and by bringing to light issues on which there is fundamental agreement. It also helps ensure a fair trial by increasing the likelihood that all the relevant evidence will be revealed while minimizing the incidence of unfair surprise at trial.

Viewing the privilege exception against this background, one can see that regarding the exception as absolute does not conflict with the purposes of discovery. First, the problem of unfair surprise is irrelevant: a plaintiff would have no conceivable motivation to invoke the privilege with regard to possibly self-incriminating matter at deposition, and then surprise his opponent with it at trial. Furthermore, such information would not serve the interests of the defendant even if it were revealed to him at deposition, because the plaintiff certainly would invoke the fifth amendment with regard to it at trial, thus precluding its use.

This last point can be amplified by a consideration of the definition of "privilege" under rule 26. It is settled law that "privi-

10328 U.S.C. § 2072 (1976).

104 FED. R. Crv. P. 26-37.

${ }_{105}$ Developments in the Law-Discovery, 74 HaRv. L. REv. 940, 944 (1961) [hereinafter cited as Developments]. 
lege" in the Federal Rules is defined by "privilege" in the law of evidence. ${ }^{106}$ Unlike exclusionary rules, privileges are not concerned with the prejudicial or probative value of the information sought. Instead, privileges exist to serve "social interest[s] extrinsic to litigation that [are] deemed sufficiently important to require that certain matters remain confidential, no matter how probative they may be. Disclosure of such matters under any circumstances would tend to defeat the purpose of the privilege." ${ }^{107}$ Because privilege in discovery by definition serves the same purpose, then by analogy it should not matter whether the information as to which the plaintiff claims the privilege on deposition is essential to the defendant's case. If the defendant would not be able to employ such information at trial, there is no reason why he should be entitled to it at the discovery stage.

\section{B. The Constitutional Limits of Rule 37 Sanctions}

Further support for a standard of absolute protection may be found in rule 37, the rule under which courts have dismissed the suits of plaintiffs who have invoked the fifth amendment on deposition. ${ }^{108}$ Rule 37 is meant to apply to the failure to make discovery under certain circumstances; these circumstances do not include the proper invocation of a privilege..$^{109}$

106 United States v. Reynolds, 345 U.S. 1, 6 (1953).

107 Developments, supra note 105, at 1009 (footnotes omitted); accord, C. McCormick, HANDBOOK OF THE LAF OF EVIDENCE \& 72, at 152 (2d ed. 1972).

108 The rule, which provides for sanctions for the failure to submit to discovery, may be set in motion only by the failure to comply with a court order compelling discovery. Thus a party seeking discovery from a recalcitrant deponent must first obtain an order pursuant to rule 37(a); rule 37 (b) sanctions will then be applicable for failure to comply with this order. Although some courts have tried to dismiss for such failures under rule 41 , the rule governing dismissals in general, see Von der Heydt v. Rogers, 251 F.2d 17 (D.C. Cir. 1958); Hubbard v. Baltimore \& O.R.R., 249 F.2d 885 (6th Cir. 1957); First Iowa Hydro Electric Cooperative v. Iowa-Illinois Gas \& Elec. Co., 245 F.2d 613 (8th Cir.), cert. denied, 355 U.S. 871 (1957); Societé Internationale v. Brownell, 225 F.2d 532 (D.C. Cir. 1955), rev'd sub nom. Societé Internationale v. Rogers, 357 U.S. 197 (1958); Mooney v. Central Motor Lines, Inc., 222 F.2d 569 (6th Cir. 1955), the Supreme Court has criticized that practice, Societe Internationale v. Rogers, 357 U.S. 197, 207 (1958). See generally Rosenberg, Sanctions to Effectuate Pretrial Discovery, 58 Colum. L. REv. 480, 484-85 (1958).

109 A number of commentators have noted the due process limitations on the imposition of sanctions under rule 37. See Developments, supra note 105, at 989-90; Note, The Emerging Deterrence Orientation in the Imposition of Discovery Sanctions, 91 Harv. L. Rev. 1033 (1978); Note, The Constitutional Limits of Discovery, 35 IND. L.J. 337, 337, 348 50 (1960). See also Commentary, Penalizing the Civil Litigant Who Invokes the Privilege Against Self-Incrimination, 24 U. FuA. L. REv. 541 (1972); Note, Use of the Privilege Against Self-Incrimination in Civil Litigation, 52 VA. L. REv. 322 (1966). 
The Supreme Court has addressed the constitutionality of discovery sanctions in a number of decisions. The development of the Court's reasoning is significant. In the 1897 case of Hovey v. Elliot, ${ }^{110}$ the defendant's answer had been stricken and a decree pro confesso entered because he had refused to obey a court order. The Court held that due process had been denied because the defendant had not been allowed to defend the action and because a decree had been entered without any hearing.

This holding was distinguished in Hammond Packing Co. $v$. Arkansas, ${ }^{111}$ in which the Court affirmed a default judgment that had been entered following a company's refusal to produce books and witnesses ordered by the court in a state antitrust action. The Court found that Hovey was not controlling. In Hovey, the Court said, "due process of law was denied by the refusal to hear"; 112 in the present case, "the preservation of due process was secured by the presumption that the refusal to produce evidence material to the administration of due process was but an admission of the want of merit in the asserted defense."113 The Court stressed that

[t]he proceeding here taken may therefore find its sanction in the undoubted right of the lawmaking power to create a presumption of fact as to the bad faith and untruth of an answer begotten from the suppression or failure to produce the proof ordered, when such proof concerned the rightful decision of the cause. ${ }^{114}$

Most importantly, the Court emphasized that in Hammond the party had not been penalized "for a failure to do that which it may not have been in its power to do,"115 and that "any reasonable showing of an inability to comply would have satisfied the requirements."116

110167 U.S. 409 (1897).

111212 U.S. 322 (1909).

112 Id. at 351.

113 Id.

114 Id. at 350-51.

${ }^{115}$ Id. at 347.

118 Id. In the original rule 37 the Advisory Committee was careful to state that the rule had been drafted "in accord with Hammond . . . , which distinguishes between the justifiable use of such measures as a means of compelling the production of evidence, and their unjustifiable use, as in Hovey . . . , for the mere purpose of punishing for contempt." Fed. R. Civ. P. 37, Adv. Comm. Notes, 28 U.S.C. at 871 (Supp. V 1939). 
The bad-faith question raised in Hammond was the focus of the important 1958 decision Societé Internationale $v$. Rogers. ${ }^{117}$ The plaintiff's action had been dismissed because of his failure to produce documents under an order issued pursuant to rule 34 . The plaintiff had tried to comply with the order, but had not been able to do so because such disclosure would have been a crime under the controlling Swiss law.

The Court stressed that Hovey and Hammond had established that "there are constitutional limitations upon the power of courts, even in aid of their own valid processes, to dismiss an action without affording a party the opportunity for a hearing on the merits of his cause."118 It then stated:

These two decisions leave open the question whether Fifth Amendment due process is violated by the striking of a complaint because of a plaintiff's inability, despite good-faith efforts, to comply with a pretrial production order. The presumption utilized by the Court in the Hammond case might well falter under such circumstances. . . . Certainly substantial constitutional questions are provoked by such action. ${ }^{119}$

The Court did not distinguish "refusal" to comply from "failure," holding that a failure to respond to a rule 37 order is cause for a finding of noncompliance under the rule regardless of whether the failure could not have been avoided in good faith. The sanction of dismissal, however, could not be imposed if the failure to comply resulted from an inability to do so. The Court emphasized that "[r]ule 37 should not be construed to authorize dismissal of this complaint because of petitioner's noncompliance with a pretrial production order when it has been established that failure to comply has been due to inability, and not to willfulness, bad faith, or any fault of petitioner." ${ }^{\prime 20}$ In accordance with Societé, which recently was reaffirmed by the Supreme Court, ${ }^{121}$ courts no longer impose severe sanctions on parties who have made good-faith ef-

${ }^{117} 357$ U.S. 197 (1958).

218 Id. at 209.

110 Id. at 210.

120 Id. at 212 (footnote omitted). In its 1970 Amendments, the Advisory Committee eliminated "willful" and "refusal" to disclose, and stated that even a negligent failure to disclose would fall under the rule, but that willfulness would affect the sanction chosen. Notes of Advisory Committee on 1970 Amendment to Rules, FED. R. Crv. P. 37, 48 F.R.D. 538-42 (1970).

121 National Hockey League v. Metropolitan Hockey Club, Inc., 427 U.S. 639 (1976) (per curiam). 
forts to comply with discovery. ${ }^{122}$

The proper invocation of a privilege at deposition, almost by definition, falls within a good-faith inability to comply with discovery; it is, after all, an exception to discovery granted by rule 26(b)(1) itself. It seems clear, therefore, that the use of rule 37 to dismiss a suit when a plaintiff invokes the fifth amendment on deposition exceeds the constitutional limits of discovery.

\section{Adverse Inference in the Civil Context}

Another reason that discovery/privilege jurisprudence, as evidenced by the cases dismissing plaintiffs' suits, developed so unsatisfactorily might be lack of clarity until fairly recently concerning the proper result of the invocation of a privilege at the trial stage of a civil suit. This uncertainty has been resolved by the Supreme Court. In Baxter v. Palmigiano, ${ }^{123}$ the Court held that the fifth amendment " 'does not preclude [an adverse] inference where the privilege is claimed by a party to a civil cause." "124 That an adverse inference may be drawn from the plaintiff's invocation of the fifth amendment in the civil trial context offers strong support for a standard of absolute protection for such an invocation at the discovery stage, for two reasons.

First, it casts dismissal of a suit for the invocation of a privilege at the discovery stage into disrepute, because the only result of such an invocation at trial is that an adverse inference may be drawn. Second, the adverse inference serves those interests of the defendant that courts have seen as competing with the interests of the plaintiff. By allowing an adverse inference to be drawn from the plaintiff's invocation of the fifth amendment at trial, the defendant is not thwarted in his defense because of the plaintiff's refusal to divulge essential information. Given the range of other evidence that may be elicited and presented at trial, the interests

122 See generally Annot., 2 A.L.R. Fed. 811 (1969).

123425 U.S. 308 (1976).

124 Id. at 318 (quoting J. WIGMORE, Evidence § 2272, at 439 (McNaughton rev. ed. 1967)) (emphasis in original). The Justice court, although not endorsing absolute protection, utilized this fact:

Nothing we have said here, however will prevent Defendant from cross examination of the Plaintiff at trial if the Plaintiff should then take the witness stand to testify. If the Plaintiff at that time refuses to answer relevant questions on the ground of his immunity an adverse inference against him may be considered by the fact finder.

78 F.R.D. at 203. Similarly, citing Baxter, the Campbell court concluded that "our holding in this case would not forbid the drawing of an adverse inference at trial." 592 F.2d at 1058. 
of both the plaintiff and the defendant in achieving a just adjudication are met: the plaintiff may maintain both his suit and his fifth amendment privilege, and the defendant may have an adverse inference drawn in his favor by the trier of fact as to the content of the withheld information. This approach obviates the need for concern about situations in which the information sought at the deposition is central to the defendant's case. ${ }^{125}$ In such situations, the chance that the plaintiff will overcome the adverse inference through other evidence is reduced, and the defendant will not be jeopardized by the plaintiff's invocation. The less essential the information sought, the greater the likelihood that the plaintiff will be able to mitigate the adverse inference by other evidence, and the interests of both parties are again well served.

\section{CONCLUSION}

The proper result of a plaintiff's invocation of the fifth amendment at deposition has been disputed by courts. The predominating approach would dismiss the plaintiff's suit on the ground that it would be unfair to allow a plaintiff to bring suit and then to thwart a defendant's discovery. Such an approach is seriously flawed: to call plaintiff a "voluntary" party is to indulge in a purely semantic distinction, because plaintiffs are usually seeking redress for some action of a defendant. As a result, such an approach can seriously jeopardize the rights of complainants who may be forced to forego their suits in order to maintain their silence.

After the Supreme Court's decision in Spevack, the lower courts found that the automatic imposition of dismissal made plaintiffs' invocation of the privilege impermissibly "costly." Although this reasoning represented an improvement over the earlier doctrine, Spevack did not address the fundamental question of whether a plaintiff should be treated differently than a defendant with regard to invoking a privilege at deposition. Furthermore, the notion of costliness did not resolve what the courts perceived as the plaintiff's and defendant's competing claims.

${ }^{125}$ See, e.g., Brown v. Ames, 346 F. Supp. 1176 (D. Minn. 1972), in which teenage youths brought suit under the federal civil rights statutes against several police officers, charging that the plaintiffs had been arrested without legal cause and with violence. Relying on Lyons, the court dismissed the suit although the plaintiffs had given 250 pages of deposition testimony, because they had refused to answer questions relating to their activities on the evening prior to arrest on the ground that to do so would be incriminating. This information was potentially central to a defense against the plaintiffs' charge that they had been arrested without legal cause. 
Recently, the Fifth and Ninth Circuits have manifested a different attitude from that of the courts in earlier cases, by recognizing the importance of the privilege exception to discovery granted by rule $26(b)(1)$. Their concern with what they viewed as defendants' competing claims, however, ultimately overshadowed their appreciation of the mandatory nature of the privilege exception.

This comment has demonstrated that a plaintiff's proper invocaton of the fifth amendment on deposition should never result in dismissal. The privilege exception granted by rule 26 is absolute; discovery, although broad, has necessary boundaries of scope and purpose. Furthermore, sanctions imposed under rule 37 may not exceed their constitutional limit. It would be an abuse of discretion for any court to dismiss a suit as a result of an invocation at the discovery stage, because a plaintiff's invocation at the trial itself can result at most in an adverse inference being drawn by the trier of fact. That such an inference may be drawn also resolves the problem of centrality: the more essential to the defendant the information sought, the more difficult it will be for the plaintiff to mitigate the adverse inference by other evidence. This approach therefore furthers both parties' right to a fair adjudication; at the same time, it upholds the plaintiff's fifth amendment right of silence. 